\title{
Seed Germination in Miconia theaezans (Bonpl.) Cogniaux (Melastomataceae)
}

\author{
Simone Godoi ${ }^{1}$ and Massanori Takaki ${ }^{2} *$ \\ ${ }^{1}$ Universidade Metodista de Piracicaba; Faculdade de Ciências Matemáticas e da Natureza; Campus Taquaral; \\ Rodovia do Açúcar, km. 156; Piracicaba - SP - Brasil. ${ }^{2}$ Departamento de Botânica; Universidade Estadual \\ Paulista; C.P.: 199; 13506-900; Rio Claro - SP - Brasil
}

\begin{abstract}
The effects of light and temperature were studied on the seeds of Miconia theazeans by isothermic and alternating temperature incubations. The optimum temperature for seed germination was determined by final percentage and germination rates as located in the range of 27.5 to $30{ }^{\circ} \mathrm{C}$ and by germination kinetics at the range of 19.5 to $30{ }^{\circ} \mathrm{C}$. The germination was dependent on diffusion processes. The minimum and maximum temperatures were $12.5-15{ }^{\circ} \mathrm{C}$ and $32.5-35^{\circ} \mathrm{C}$, respectively. The seeds showed strong light dependence for germination with the necessity of daily 4-6 $\mathrm{h}$ white light irradiation for the maximum induction of germination. However, under $30-20{ }^{\circ} \mathrm{C}$ alternating temperatures, daily 2 hours white light was enough to induce germination and attained maximum under $4 \mathrm{~h}$ photoperiod. The results indicated that $\mathrm{M}$. theazeans presented characteristics of early successional species.
\end{abstract}

Key words: Light, seed germination, temperature

\section{INTRODUCTION}

Decrease in the biodiversity of plants in tropical forests is the main consequence of human activities, especially in the Atlantic forest. The knowledge of the dynamics of reproduction responses, such as pollination, dispersion and germination of seeds in disturbed areas is important for the management and conservation of natural forests and for reforestation (Bruna 1999). Regeneration processes in a tropical forest are associated to the dynamic of secondary succession with colonization by species with ecophysiological adaptation to different environmental conditions (Gómez-Pompa et al. 1991).

Gaps in the canopy formed by the fall of one or more trees are important for the maintenance of the biodiversity of species in a tropical forest (Hartshorn, 1980). In this case, the maintenance of biodiversity is related to the number of species that occur in the forest and the presence of seeds in the soil seed bank. Pioneer species present characteristics which are important for the colonization of gaps of the forest (Whitmore 1990). Whitmore (1989) classified plant species in two successional categories: i. pioneer and ii. nonpioneer species. Earlier, Budowski (1965) classified plant species in four categories: i. pioneers, which are found in large gaps of the canopy, with fast growth, producing high number of small seeds which are dispersed by animals forming soil seed bank; ii. early secondary species, similar to pioneer species, but found in smaller gaps; iii. late secondary and iv. climax species

\footnotetext{
${ }^{*}$ Author for correspondence
} 
found in the shade of the canopy with slow development rate.

Species in the secondary succession can be classified in three distinct categories: i. specialists of large gaps, with dormant seeds which germinate only under high temperature or high light fluences and present shade avoidance responses; ii. specialists of small gaps, with seeds that germinate under the canopy and iii. specialists of canopy, with seeds and seedlings which do not need full sun for germination and seedling development (Denslow 1980). Seeds of pioneer species, found in the soil seed bank, require light with high fluence and R:FR ratio, high temperature or alternating temperature for germination and those conditions can be found in gaps of forest canopies (Kyereh et al. 1999, Kageyama et al. 1990, Bazzaz 1984).

Miconia theaezans (Melastomataceae) is found from Central America to State of Santa Catarina in Brazil; in São Paulo State it is found in gallery forests. M. theaezans is classified as early secondary species (Knobel 1995). It produces fruits which are eaten especially by bird, responsible for dispersion of its seeds. Baider et al. (1999) working with composition of soil seed bank at Atlantic forest and colonization of natural gaps, found species mainly from the Melastomataceae, especially Miconia, Leandra and Rapanea. Melastomataceae species are reported to be important for the forest restoration programs (Macedo 1993) to improve biodiversity of the resulting forest by attracting different seed dispersers.

The aim of the present work was to study the cardinal and the optimal temperatures as characteristics of $M$. theaezans seed germination. The interaction of temperature and light was also analyzed for determination of seed behavior to give information for the management and conservation of $M$. theaezans in natural forests and for reforestation of disturbed areas projects.

\section{MATERIAL AND METHODS}

Seeds of M. theaezans (Bonpl.) Cogniaux were obtained from fruits harvested in an area of Atlantic Forest at São Bernardo do Campo city, State of São Paulo, Brazil. The fruits were ground in a becker with the aid of a pistil and water. The seeds with fruit parts were cleaned with a sieve and dried at a constant temperature of $25^{\circ} \mathrm{C}$. Dried seeds were stored inside a stoppered jar and maintained at $5{ }^{\circ} \mathrm{C}$ during one year. The experiments started just after the seeds were collected. For germination tests, $50 \mathrm{~mm}$ diameter Petri dishes were used with two layers of water imbibed filter paper inside. The Petri dishes were kept inside dark plastic boxes for dark treatments and colorless plastic boxes for light treatments. Constant temperatures were obtained with incubators. Due to the small seed size, around 200 seeds were put inside each Petri dish, as proposed by Cone and Kendrick (1985) for seeds of Arabidopsis thaliana (L.) Heynh.

Germinated seeds were counted daily and seeds with at least $1 \mathrm{~mm}$ long roots were considered as germinated. Dark incubated seeds were observed under a dim green safe light (Amaral-Baroli and Takaki 2001). The experiments were finished when seeds did not germinate at least for 5 successive counts and last 50 days under sub and supra optimum temperatures.

Different temperatures were tested $\left(10-35{ }^{\circ} \mathrm{C}\right.$ with $2.5^{\circ} \mathrm{C}$ intervals) and the photoperiod effect was tested at $27.5^{\circ} \mathrm{C}$. Alternating temperatures (30-20 ${ }^{\circ} \mathrm{C}, 25-20{ }^{\circ} \mathrm{C} ; 22.5-20{ }^{\circ} \mathrm{C} ; 35-20{ }^{\circ} \mathrm{C}$ e $30-15{ }^{\circ} \mathrm{C}$ ) were tested with $12 \mathrm{~h}$ photoperiod. At $20-30{ }^{\circ} \mathrm{C}$ alternating temperatures different photoperiods were tested. White light at $8.93 \mu$ mol. $\mathrm{m}^{-2} . \mathrm{s}^{-1} \cdot \mathrm{nm}^{-1}$ was obtained with the aid of two $15 \mathrm{~W}$ day light fluorescent lamps and measured with a LI-1800 spectroradiometer (LI-COR, U.S.A.).

The final percentage $(\mathrm{G})$, rate of germination (GR) and germination synchronization index (SI) were calculated according to Labouriau and Agudo (1987). Analysis of kinetics of seed germination was conducted according to Labouriau and Osborn (1984) using the variation in the enthalpy of activation of seed germination $\Delta \mathrm{H} \# \eta=\{[\mathrm{R} . \mathrm{T}(\theta-$ $\mathrm{T}) .(\mathrm{Tm}-\mathrm{TM})] /[(\mathrm{T}-\mathrm{Tm}) .(\mathrm{TM}-\mathrm{T})]\}$; where $\mathrm{R}$ is the gas universal constant of $1.987 \mathrm{cal}$; $\mathrm{Tm}$ the minimum temperature, $\mathrm{TM}$ the maximum temperature of germination, $\theta$ the harmonic mean between $\mathrm{Tm}$ and $\mathrm{TM}$ and $\mathrm{T}$ the temperature $\left({ }^{\circ} \mathrm{K}\right)$. The effects of light and temperature were determined by the analysis of variance followed by a Student-Newman Keuls or by Kruskal-Wallis test (Zar, 1998), and an alpha level of 0.05 was adopted as significant in all circumstances. Before the analysis, the germination data were

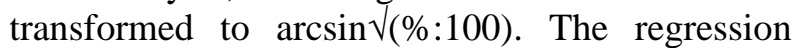
lines for effect of photoperiod on germination of seeds incubated at $27.5{ }^{\circ} \mathrm{C}$ and $30-20{ }^{\circ} \mathrm{C}$ 
alternating temperature were obtained using the logistic function, according to Hsu et al. (1984).

\section{RESULTS AND DISCUSSION}

Seeds of $M$. theaezans exposed to constant temperatures below $15{ }^{\circ} \mathrm{C}$ and above $32.5{ }^{\circ} \mathrm{C}$ did not germinate. The high values of $\mathrm{G}$ were observed between $15{ }^{\circ} \mathrm{C}$ and $32.5{ }^{\circ} \mathrm{C}$, with no significant differences observed within this range (Table 1).

The optimum temperature for germination of tropical species usually are higher than those observed for temperate species, and the seeds of several tropical species can germinate in a broad range of temperatures (Kozlowski, 2002).

Table 1 - Seed germination of Miconia theazeans under different constant temperature and continuous white light. Means \pm standard deviation for: seed germination G (\%); (GR) mean germination rate and synchronization index (SI). Means followed by the same letter are not significant at $5 \%$ level.

\begin{tabular}{cccc}
\hline Temperature $\left({ }^{\circ} \mathbf{C}\right)$ & $\mathbf{G}(\boldsymbol{\%})$ & $(\mathbf{G R})$ & $(\mathbf{S I})$ \\
\hline 10.0 & 0 & - & - \\
12.5 & 0 & - & - \\
15.0 & $89.0 \pm 9.40^{\mathrm{a}}$ & $0.036 \pm 0.0002^{\mathrm{e}}$ & $2.55 \pm 0.13^{\mathrm{a}}$ \\
17.5 & $90.0 \pm 1.87^{\mathrm{a}}$ & $0.062 \pm 0.0022^{\mathrm{d}}$ & $3.41 \pm 0.02^{\mathrm{a}}$ \\
20.0 & $96.3 \pm 4.57^{\mathrm{a}}$ & $0.077 \pm 0.0029^{\mathrm{c}}$ & $2.17 \pm 0.20^{\mathrm{a}}$ \\
22.5 & $97.4 \pm 1.29^{\mathrm{a}}$ & $0.111 \pm 0.0007^{\mathrm{b}}$ & $2.11 \pm 0.16^{\mathrm{a}}$ \\
25.0 & $95.3 \pm 2.68^{\mathrm{a}}$ & $0.111 \pm 0.0012^{\mathrm{b}}$ & $1.94 \pm 0.23^{\mathrm{a}}$ \\
27.5 & $97.1 \pm 1.95^{\mathrm{a}}$ & $0.115 \pm 0.0018^{\mathrm{a}}$ & $2.36 \pm 0.06^{\mathrm{a}}$ \\
30.0 & $98.2 \pm 1.30^{\mathrm{a}}$ & $0.114 \pm 0.0009^{\mathrm{a}}$ & $2.05 \pm 0.17^{\mathrm{a}}$ \\
32.5 & $97.4 \pm 0.88^{\mathrm{a}}$ & $0.105 \pm 0.1052^{\mathrm{b}}$ & $2.24 \pm 0.08^{\mathrm{a}}$ \\
35.0 & 0 & - & - \\
\hline
\end{tabular}

An increase in the mean germination rate was observed as temperature increased from 15 to 22.5 ${ }^{\circ} \mathrm{C}$. No difference was observed in mean germination rate between 27.5 and $30{ }^{\circ} \mathrm{C}$, as well as between 22.5 and $25^{\circ} \mathrm{C}$. However, these values were significantly different from any other tested isotherms. According to Labouriau and Osborn (1984), the rate of seed germination was limited only by diffusion processes at $|\Delta \mathrm{H} \# \mathrm{n}|<12$ $\mathrm{kcal}^{\mathrm{mol}}{ }^{-1}$ which in seeds of $M$. theazeans occurred under temperatures ranges of 19.5 to 30.0 ${ }^{\circ} \mathrm{C}$ (Fig. 1). Thus, the optimum temperature for the germination of seeds of $M$. theazeans must be in this range of temperature. The statistical analysis indicated that the optimum temperature was between 27.5 and $30.0{ }^{\circ} \mathrm{C}$, which could be considered high confirming the behavior of the species which colonized open areas. Similar results were obtained by Ferraz-Grande and Takaki (2001) in the seeds of Dalbegia nigra Allem. with optimum temperature at $30.5^{\circ} \mathrm{C}$ and range of temperature with seed germination from 15 to $40{ }^{\circ} \mathrm{C}$, and by Andrade (1995) in the seeds of Tibouchina benthaminana, Tibouchina grandifolia, Tibouchina moricandiana and Leandra breviflora, with $30^{\circ} \mathrm{C}$ as optimum temperature.
Souza and Válio (2001) reported that seeds of pioneer species of Solanum granuloso-leprosum Dun., Trema micrantha (L.) Blume and Cecropia pachystachya Trec., when exposed to continuous dark at $25{ }^{\circ} \mathrm{C}$ did not germinate, but under the same temperature and continuous white light, the germination of $C$. pachystachya was $84 \%$, while $S$. granuloso-leprosum showed $4.8 \%$ of germination and T. micrantha $2.5 \%$. 


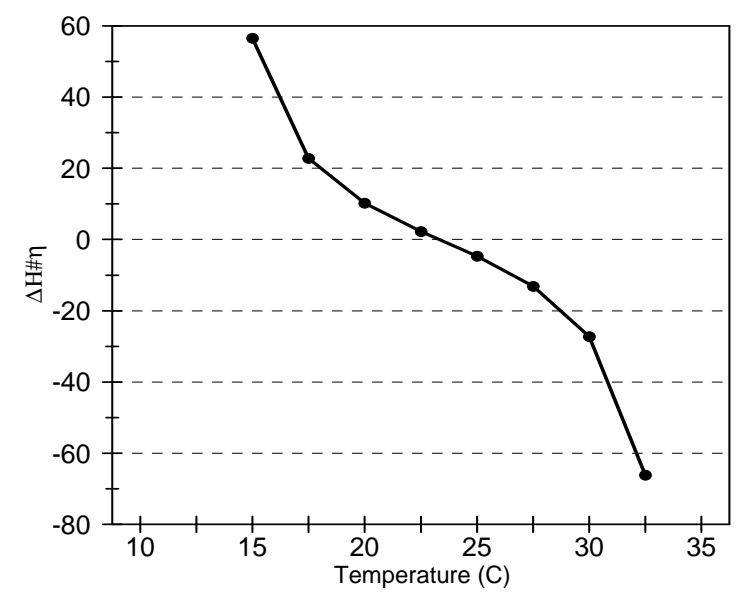

Figure 1 - Variation in enthalpy of activation $(\Delta \mathrm{H} \# \eta)$ of seed germination in M. theazeans

Present data showed that at constant $27.5^{\circ} \mathrm{C}$, a two hours daily light treatment were not enough to promote germination, and under a photoperiod of $4 \mathrm{~h}$ only $14.1 \%$ of the seeds germinated. Above this photoperiod, an increase in the percentage of germination was observed with increase in the photoperiod. The highest percentage of germination was found between the photoperiods of 6 and $12 \mathrm{~h}$ and in the later condition $97.5 \%$ of the seeds germinated (Fig. 2). The values of mean germination rate increased with increase in the photoperiod and small decrease was observed at
$12 \mathrm{~h}$ photoperiod. The highest mean germination rate was observed at $10 \mathrm{~h}$ photoperiod, and all the values differed significantly from each other (Table 2).

Alseis blackiana Hemsl. is an abundant species in the canopy forest, with seedlings that can only be found in gaps. Its germination was tested in a gap and under the canopy; the results showed a higher germination in the gap $(40 \pm 9 \%)$ than under the canopy $(8 \pm 2 \%)$.

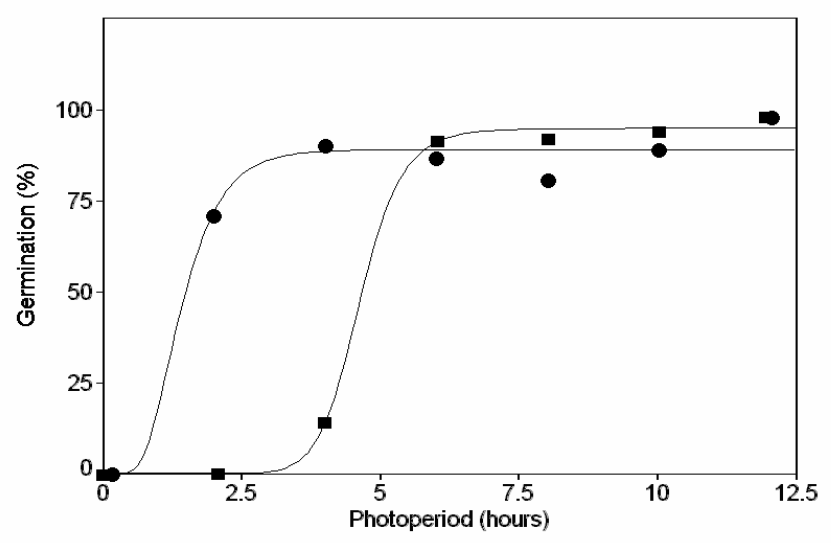

Figure 2 - Effect of photoperiod on germination of seeds of Miconia theaezans incubated at 27.5 ${ }^{\circ} \mathrm{C}(--)$ and under alternating $30-20{ }^{\circ} \mathrm{C} \mathrm{(- \bullet -).} \mathrm{Lines} \mathrm{represent} \mathrm{the} \mathrm{regression} \mathrm{obtained}$ by logistic function with $\mathrm{r}^{2}=0.998 \mathrm{~F}=873.5$ for $\left(-\boldsymbol{-}_{-}\right)$and $\mathrm{r}^{2}=0.978 \mathrm{~F}=91.7$ for $(-\bullet-)$. 
Thus, this species seemed to be able to survive under the canopy leading to the high capacity of light absorption (even from occasional sun flecks) and the fast growing in the initial period (Dalling et al. 2001).

The lowest values for the germination synchronization index of $M$. theazeans were found under a photoperiod of 10 and $12 \mathrm{~h}$. No difference was observed between the values obtained at 4 and $6 \mathrm{~h}$ and between 6 and $8 \mathrm{~h}$. Germination under a photoperiod of 4 hours was slow and less synchronized than under $12 \mathrm{~h}$ photoperiod, when the seeds germinated in a higher and synchronized germination.

Ekstam and Forsebay (1999) reported that seeds of Phragmites australis (Cav.) Trin. Ex Steudel and Typha latifolia L. germinated after dispersion under low mean daily temperatures, as long as the range of variation was wider. However, the seeds that were dispersed in unfavorable seasons, such as in autumn and winter, when mean daily temperatures were lower and with narrow range, could not germinate until the soil was warmed and the range of thermal variation increases. Benvenuti et al. (2001) observed that alternating temperatures had an ecological relevance for seedling emergence under natural conditions, and that daily fluctuation in temperatures could be more important as an environmental clue than light for triggering the germination of seeds that are close to the soil surface.

Bazzaz and Pickett (1980) reported that the temperature in the forest soil showed small difference from air temperature. This difference can be substantial in gaps, where daily variation in temperature range from $25^{\circ} \mathrm{C}$ at night up to $42{ }^{\circ} \mathrm{C}$ during the day. Bazzaz (1984) mentioned that seeds of the initial stage of secondary succession germinated under micro clime conditions associated with alternating temperatures. These ideas were corroborated by Kyereh et al. (1999) who indicated that the gap formation is associated with changes in the range of temperature and in the maximum temperature, as well as in the water availability in the soil. Evidently, light sensitivity of the seeds was a feature of several pioneer species and was associated with the small seeds that usually composed the soil seed bank. Psidium guajava, a gap colonizing species, present light sensitive seeds which germinate in darkness under alternating temperatures, while under constant temperature they germinate only under white light (Sugahara and Takaki 2004). Thus gap and open area colonizing species can present different behavior under different temperatures.

Table 2 - Seed germination of Miconia theazeans under constant $27.5^{\circ} \mathrm{C}$ and different light regimes. Means \pm standard deviation for: seed germination $\mathrm{G}(\%)$; (GR) mean germination rate and synchronization index (SI). Means followed by the same letter are not significant at $5 \%$ level.

\begin{tabular}{ccc}
\hline Light regimes $(\mathbf{h})$ & $(\mathbf{G R})$ & $(\mathbf{S I})$ \\
\hline 0 & - & - \\
2 & - & - \\
4 & $0.034 \pm 0.0009^{\mathrm{d}}$ & $3.27 \pm 0.47^{\mathrm{a}}$ \\
6 & $0.062 \pm 0.0013^{\mathrm{c}}$ & $2.95 \pm 0.23^{\mathrm{ab}}$ \\
8 & $0.073 \pm 0.0018^{\mathrm{b}}$ & $2.67 \pm 0.17^{\mathrm{b}}$ \\
10 & $0.118 \pm 0.0033^{\mathrm{a}}$ & $2.04 \pm 0.18^{\mathrm{c}}$ \\
12 & $0.098 \pm 0.0007^{\mathrm{b}}$ & $1.88 \pm 0.22^{\mathrm{c}}$ \\
\hline
\end{tabular}

Alternation of $35-20 \quad{ }^{\circ} \mathrm{C}$ did not promote germination of $M$. theazeans seeds than isothermic incubations. Germination was higher at an alternating $30-20{ }^{\circ} \mathrm{C}$ than other treatments. No difference was found between $22.5-20{ }^{\circ} \mathrm{C}$ and 25 $20{ }^{\circ} \mathrm{C}$ and between $22.5-20{ }^{\circ} \mathrm{C}$ and $30-15{ }^{\circ} \mathrm{C}$ alternating temperatures (Table 3 ). The seeds did not germinate in the dark under all treatments. Mean rate of germination of $M$. theazeans differed statistically among all alternating temperature treatments and higher values were observed under an alternation of $22.5-20{ }^{\circ} \mathrm{C}$ and $25-20{ }^{\circ} \mathrm{C}$, while the lowest value was observed under the alternation of $30-20{ }^{\circ} \mathrm{C}$.

Under $30-20{ }^{\circ} \mathrm{C}$ alternating temperatures, high values of percentage of germination were observed between photoperiods of 4 to $12 \mathrm{~h}$ (Fig. 2). However, two hours photoperiod was enough to 
induce high percentage germination while at 27.5 ${ }^{\circ} \mathrm{C}$ isothermic incubations two hours photoperiod did not induce germination. Data for mean rate of germination showed that the highest value was observed under a photoperiod of $12 \mathrm{~h}$, and that this value differed from all other values. On the other hand, no significant differences were observed between the photoperiods of 6 and $10 \mathrm{~h}$ and between the photoperiods of 2 and $8 \mathrm{~h}$ (Table 4). In some species such as Trema micrantha, germination was promoted under alternating temperatures and the mean germination rate was higher at alternating temperatures of $20-30{ }^{\circ} \mathrm{C}$ and e 30-40 ${ }^{\circ} \mathrm{C}$ (Castellani and Aguiar, 2001). Our results indicate that seeds of $M$. theaezans present increase in light sensitivity when under alternating temperatures, a condition present in gaps and open areas (Bazzaz and Pickett 1980).

Table 3 - Seed germination of Miconia theazeans under alternating temperatures. Over 12h light (higher temperature) and $12 \mathrm{~h}$ dark (lower temperature). Means \pm standard deviation for: seed germination G (\%); (GR) mean germination rate and synchronization index (SI). Means followed by the same letter are not significant at $5 \%$

\begin{tabular}{cccc}
\hline $\begin{array}{c}\text { Temperatures } \\
\left({ }^{\circ} \mathbf{C}\right)\end{array}$ & $\mathbf{G ~ ( \% )}$ & $(\mathbf{G R})$ & $($ SI $)$ \\
\hline $30.0-20.0$ & $97.4 \pm 0.01^{\mathrm{c}}$ & $0.056 \pm 0.0007^{\mathrm{a}}$ & $2.05 \pm 0.16^{\mathrm{ac}}$ \\
$25.0-20.0$ & $95.7 \pm 0.01^{\mathrm{a}}$ & $0.094 \pm 0.0017^{\mathrm{b}}$ & $2.43 \pm 0.16^{\mathrm{bc}}$ \\
$22.5-20.0$ & $94.9 \pm 0.01^{\mathrm{ab}}$ & $0.084 \pm 0.0008^{\mathrm{c}}$ & $2.32 \pm 0.10^{\mathrm{ab}}$ \\
$35.0-20.0$ & 0 & - & - \\
$30.0-15.0$ & $86.9 \pm 0.06^{\mathrm{b}}$ & $0.081 \pm 0.0012^{\mathrm{d}}$ & $2.41 \pm 0.20^{\mathrm{d}}$ \\
\hline
\end{tabular}

level.

Judging from the results obtained for the synchronization index under $12 \mathrm{~h}$-photoperiod, germination was more synchronized and differed statistically from the values obtained under all other photoperiods. There was no significant difference among the photoperiods of 2,8 and 10 $\mathrm{h}$, as well as among the photoperiods of $2,4,6,8$ and $10 \mathrm{~h}$ (Table 4). Garwood (1989) pointed out that under natural conditions, non-synchronized germination might give an adaptive advantage. Under this condition, the seed can be kept in the soil seed bank until favorable conditions trigger germination and, thus, the onset of the succession process. This fact can also be responsible for the biodiversity maintenance.

Table 4 - Seed germination of Miconia theazeans under alternating temperature $30-20{ }^{\circ} \mathrm{C}$ and different photoperiods of white light. Means \pm standard deviation for: (GR) mean germination rate and synchronization index (SI). Means followed by the same letter are not significant at $5 \%$ level.

\begin{tabular}{ccc}
\hline Light regimes $(\mathbf{h})$ & $(\mathbf{G R})$ & $($ SI) \\
\hline 0 & - & - \\
2 & $0.046 \pm 0.0028^{\mathrm{b}}$ & $3.58 \pm 0.31^{\mathrm{bc}}$ \\
4 & $0.050 \pm 0.0009^{\mathrm{a}}$ & $3.93 \pm 0.15^{\mathrm{c}}$ \\
6 & $0.053 \pm 0.0002^{\mathrm{d}}$ & $3.83 \pm 0.08^{\mathrm{c}}$ \\
8 & $0.047 \pm 0.0014^{\mathrm{b}}$ & $3.62 \pm 0.29^{\mathrm{bc}}$ \\
10 & $0.050 \pm 0.0011^{\mathrm{a}}$ & $3.66 \pm 0.11^{\mathrm{bc}}$ \\
12 & $0.056 \pm 0.0007^{\mathrm{c}}$ & $2.05 \pm 0.16^{\mathrm{a}}$ \\
\hline
\end{tabular}

The results indicated that light was the main factor that drived the germination of the seeds of $M$. theazeans, since in no other experimental conditions germination was observed under dark conditions. Overall, under light conditions, the seeds from this species showed higher percentage of germination under both the constant (ca. 87\%), and under alternating temperatures (ca. 90\%). Interaction between alternating temperature and 
light indicated that seeds of $M$. theaezans germinated in canopy free areas.

In summary, the seeds of $M$. theazeans, germinated better under experimental conditions that resembled those naturally found in canopy gaps and open areas with broad range of alternating temperature and long photoperiods. Thus, M. theaezans, in natural forest, was important for colonizing large gaps and other disturbed areas due to the germination characteristics presented in the present work. Since the germination of $M$. theaezans seeds occurred only under light, the seeds probably are maintained in the soil as seed bank, thus, maintaining the biodiversity of the forest. Summing these facts to the dispersion of seeds made by birds (Knobel, 1995) M. theaezans could be a good species with early sucessional characteristics in reforestation projects.

\section{RESUMO}

O efeito da luz e da temperatura na germinação de sementes de Miconia theazeans foi analisado através de incubações isotérmicas e de alternâncias de temperaturas. Através das porcentagens finais e velocidade de germinação concluímos que a temperatura ótima de germinação localizaram-se entre 27,5 e $30{ }^{\circ} \mathrm{C}$ e pela cinética de germinação verificamos que entre 19,5 e $30^{\circ} \mathrm{C}$ a germinação é dependente de processos de difusão. As temperaturas mínima e máxima foram de 12,5-15 ${ }^{\circ} \mathrm{C}$ e 32,5-35 ${ }^{\circ} \mathrm{C}$, respectivamente. As sementes apresentaram forte dependência da presença de luz branca para a indução da germinação com a necessidade de 4-6 horas de luz diária para a máxima indução do processo. Entretanto, com a alternância de temperaturas de 30 e $20{ }^{\circ} \mathrm{C}$, fotoperíodo de 2 horas foi suficiente para a indução da germinação sendo o máximo de indução obtida a partir de 4 horas diárias. Estes resultados indicam que Miconia theazeans é uma espécie importante que coloniza clareiras e áreas perturbadas em uma floresta natural.

\section{ACKNOWLEDGEMENTS}

The authors thank Fapesp and Fundunesp for grants and CNPq for Scholarship to S. Godoi and Research Fellowship to M. Takaki.

\section{REFERENCES}

Amaral-Baroli, A. and Takaki, M. (2001) Phytochrome controls achene germination in Bidens pilosa L. (Asteraceae) by very low fluence response. Brazilian Archives of Biology and Technology 44, 121-124.

Andrade, A.C.S. (1995) Efeito da luz e da temperatura na germinação de Leandra breviflora Cogn., Tibouchina benthamina Cogn., Tibouchina grandifolia Cogn. e Tibouchina moricandiana (DC.) Baill. (Melastomataceae). Revista Brasileira de Sementes 17, 29-35.

Baider, C., Tabarelli, M. and Mantovani, W. (1999) O banco de sementes de um trecho de Floresta Atlântica Montana (São Paulo). Revista Brasileira de Biologia 59, 319-328.

Bazzaz, F.A. (1984) Dynamics of wet tropical forests and their species strategies. In: Physiological ecology of plants in the tropics. (E. Medina. H.A. Mooney and C. Vázquez-Yanes eds) J. Publishers, Boston, 233-244.

Bazzaz, F.A. and Pickett, S.T.A. (1980) Physiological ecology of tropical succession: a comparative review. Annual Review in Ecology and Systematics 11, 287310.

Benvenuti, S., Macchia, M. and Miele, S. (2001) Light, temperature and burial depth effects on Rumex obtusifolius seed germination and emergence. Weed Research 41, 177-186.

Bruna, M.E. (1999) Seed germination in rainforest fragments. Nature 402, 139.

Budowski, G. (1965) Distribution of tropical American rain forest species in the light of successional processes. Turrialba 15, 40-42.

Castellani, E.D. and Aguiar, I.B. (2001) Seed maturation and effect of temperature regime on Trema micrantha (L.) Blume seed germination. Seed Science and Technology 29, 73-82.

Cone, J.W. and Kendrick, R.E. (1985) Fluenceresponse curves and action spectra for promotion and inhibition of seed germination in wildtype and long hypocotyl mutants of Arabidopsis thaliana. Physiologia Plantarum 59, 416-420.

Dalling, J.W., Winter. K., Nason, J.D., Hubbell, S.P., Murawski, D.A. and Hambrick, J.L. (2001) The unusual life history of Aseis blackiana: a shadepersistent pioneer tree? Ecology 82, 933-945.

Denslow, J.S. (1980) Gap partitioning among tropical rainforest trees. Biotropica 12, 47-55.

Ekstam, B. and Forsebay, A. (1999) Germination response of Phragmites australis and Typha latifolia to diurnal fluctuations in temperature. Seed Science Research 9, 157-163. 
Ferraz-Grande, F.G.A. and Takaki, M. (20010 Temperature dependent seed germination of Dalbergia nigra Allem (Legumoinosae). Brazilian Archives of Biology and Technology 44, 401-404.

Garwood, N.C. (1989) Tropical soil seed banks: a review. In: Ecology of soil seed banks (M.A. Leck, V.T. Parker and R.L. Simpson, eds), Academic Press Inc. 149-209.

Gómez-Pompa, A., Whitmore, T.C. and Hadley, M. (1991) Tropical rain forest: regeneration and management. Blackwell, New York.

Hartshorn, G.S. (1980) Neotropical forest dynamics. Tropical succession. Biotropica 12, 1-47.

Hsu, F.H., Nelson, C.J. and Chou, W.S. (1984) A mathematical model to utilize the logistic function in germination and seedling growth. Journal of Experimental Botany 35, 1629-1640.

Kageyama, P.Y., Biella, I.C. and Palermo Junior, A. (1990) Plantações mistas com espécies nativas com fins de proteção a reservatórios. In: VI Congresso Florestal brasileiro, Campos do Jordão. Sociedade brasileira de Silvicultura, São Paulo, Brasil, vol.1, p. 109-113.

Knobel, M.G. (1995) Aspectos da regeneração natural dos compostos arbóreo-arbustivo, de trecho da floresta da Reserva Biológica do Instituto de Botânica São Paulo, Dissertação de Mestrado, Universidade de São Paulo, São Paulo.

Kozlowski, T.T. (2002) Physiological ecology of natural regeneration of harvested and disturbed forest stands: implications for forest management. Forest Ecology and Management 158, 195-221.

Kyereh B., Swaine, M.D. and Thompson, J. (1999) Effect of light on the germination of forest trees in Ghana. Journal of Ecology 87, 772-783.

Labouriau, L.G. and Agudo, M. (1987) On the physiology of seed germination in Salvia hispanica L. I. Temperature effects. Anais da Academia Brasileira de Ciências 59, 37-56.
Labouriau, L.G. and Osborn, J.H. (1984) Temperature dependence of the germination of tomato seeds. Journal of Thermal Biology 9, 285-294.

Macedo, A.C. (1993) Revegetação: matas ciliares e de proteção ambiental. São Paulo: Fundação Florestal, $27 \mathrm{p}$.

Sugahara, V.Y. and Takaki, M. (2004) Effect of temperature and light on seed germination in guava (Psidium guajava L. - Myrtaceae). Seed Science and Technology 32, 759-764.

Souza, R.P. and Válio, I.F.M. (2001) Seed size, seed germination, and seedling survival of brazilian tropical tree species differing in successional status. Biotropica 33, 447-457.

Whitmore, T.C. (1989) Canopy gaps and two major groups of forest trees. Ecology 70, 536-538.

Whitmore, T.C. (1990) An introduction to tropical rain forests. Blackwell, London.

Zar, J.H. 1998. Bioestatical Analyses. Prentice Hall, New Jersey. 